Bond University

Research Repository

\title{
Improving case study research in medical education: A systematised review
}

Cheek, Colleen; Hays, Richard; Smith, Janie D.; Allen, Penny

Published in:

Medical Education

DOI:

10.1111/medu.13469

Licence:

Other

Link to output in Bond University research repository.

Recommended citation(APA):

Cheek, C., Hays, R., Smith, J. D., \& Allen, P. (2018). Improving case study research in medical education: A systematised review. Medical Education, 52(5), 480-487. https://doi.org/10.1111/medu.13469

\section{General rights}

Copyright and moral rights for the publications made accessible in the public portal are retained by the authors and/or other copyright owners and it is a condition of accessing publications that users recognise and abide by the legal requirements associated with these rights.

For more information, or if you believe that this document breaches copyright, please contact the Bond University research repository coordinator. 
Improving case study research in medical education: Systematised review

Improving case study research in medical education: a systematised review

Colleen Cheek ${ }^{1}$, colleen.cheek@utas.edu.au, Richard Hays ${ }^{1}$, richard.hays@utas.edu.au, Janie Smith², JanSmith@bond.edu.au and Penny Allen¹, penny.allen@utas.edu.au

1. University of Tasmania, Faculty of Health - Rural Clinical School. Brickport Road, Burnie, Tasmania, Australia 7320

2. Faculty of Health Sciences and Medicine, Bond University, Gold Coast, Queensland, Australia

\section{Corresponding Author:}

Colleen Cheek

Rural Clinical School

College of Health and Medicine | University of Tasmania

Private Bag 3513,

Hospitals Campus,

Burnie TAS 7320

T: +61364301645

colleen.cheek@utas.edu.au 
Improving case study research in medical education: Systematised review

\section{Abstract}

\section{Introduction}

Case study research (CSR) is a research approach that guides holistic investigation of a real phenomenon. This approach may be useful in medical education to provide critical analyses of teaching and learning, and reveal the underlying elements of leadership and innovation. There are variations in the definition, design, and choice of methods, which may diminish the value of CSR as a form of inquiry. This paper reports an analysis of CSR papers in the medical education literature. We aimed to describe how CSR has been used and how more consistency might be achieved to promote understanding and value.

\section{Method}

A systematised review was undertaken to quantify the number of CSR articles published in scholarly medical education journals over the last 10 years. We applied a typology of CSR proposed by Thomas and Myers to integrate the various ways CSR is constructed.

\section{Results}

Of the 362 full-text articles assessed, 290 were excluded as they did not meet the eligibility criteria; 76 of these were titled 'case study'. Of the 72 included articles, 50 used single-case and 22 multi-case design, 46 connected with theory while 26 were atheoretical. In some articles it was unclear what the subject was, or how the subject was being analysed.

\section{Discussion}

In this study more articles titled 'case study' did not meet the eligibility criteria than those that did. Well-structured, clearly written CSR in medical education has the potential to increase understanding of more complex situations, but this review shows there is considerable variation in how it is conducted, potentially limiting utility and translation into educational practice. Case study research may be of more value in medical education if researchers more consistently followed principles of design, and harnessed rich observation with connection of ideas and knowledge to engage the reader in what is most interesting. 
Improving case study research in medical education: Systematised review

\section{Introduction}

Case Study Research (CSR) is a form of inquiry that can illuminate interesting qualities and deepen knowledge, ${ }^{1-4}$ but sometimes what is labelled 'case study' has no foundation in research and may lack purpose, integrity or connection to any analytical frame ${ }^{3}$.

Professional fields such as accounting, business, education, marketing, public administration and medicine use CSR. In higher education it is proposed that well-structured, clearly written CSR may be useful in providing critical analyses of underlying issues, identifying and challenging assumptions, and 'guiding intelligent action' ${ }^{5}$. To teach leadership in innovation to educators of health professionals, Harvard's Macy Institute use CSR about educational reform to reveal interwoven elements of change and circumstance. There is a contrasting view that CSR has no generalizability and therefore lacks scientific value ${ }^{6}$, and a misperception that 'anything goes' 7. Lack of definition, ambiguity about design, disagreement about acceptable methods, and inability to apply findings more generally can diminish the value of CSR as a method of inquiry, contribute to questions about reliability, and limit uptake of research findings $3,6,8$.

Influential CSR authors generally define CSR as a study of a contemporary, real phenomenon, which involves 'thick description' of a subject, through multiple sources of data or multiple methods ${ }^{1,2,4}$. 'Contemporary' in this context does not preclude describing events that have already happened, but it distinguishes between history as a 'dead past', and 'contemporary' where research participants have lived experience to impart.

Beyond this definition there is variation in the way CSR is conceptualised. For example, Yin (2014) describes three types of CSR - exploratory, descriptive and explanatory, in a singlecase or a multiple-case design. Single-case designs are critical, unusual, revelatory, or longitudinal in relation to the theory or propositions of interest. Within a single case there may be embedded units of analysis, but if there are distinct cases in the one study, then a multiple-case design is adopted ${ }^{4}$. Stake (2005), is more interpretive, distinguishing between an intrinsic case (where the case is dominant), and an instrumental case (where the issues are dominant); and he termed multiple cases a 'collective case' 2 . 
Improving case study research in medical education: Systematised review

Bassey (1999) differentiates between a theoretical approach where the aim is to understand or illuminate theory, and an evaluative and/or action approach ${ }^{1}$. Incorporating theory is broadly valued to guide data collection and analysis, to add to collective knowledge, or to allow ideas to be viewed differently. Some authors advocate only qualitative methods are used $^{2,9}$, while others regard the collection and analysis of quantitative data useful when it is relevant to the behaviour and events that the case is trying to explain.

Viewing the whole and acknowledging the complexity of many interacting variables is challenging in research as most scientific inquiry is about breaking things down and seeking understanding of the constituent parts ${ }^{3}$. The natural sciences enhance study reliability by isolating a few variables in many settings and pursue generalisations through induction. In contrast, CSR explores many variables in a single or few settings as it considers social settings as a synergistic interplay of variables including people and circumstance which are often indivisible ${ }^{3}$. Ideas are represented and explored, but CSR does not hide from its contextual focus or propose generalization. This worldview is most popular in the social sciences but CSR is not confined to this domain. For example, CSR may be used in public health to investigate outbreaks of disease, with epidemiological statistics used to test possible explanations derived from analysis of interviews and field observation.

The divergence of CSR from other research approaches and its use across traditionally distinct philosophies has contributed to CSR being described as an 'intellectual orphan' ${ }^{3}$, or existing in a 'methodological limbo' ${ }^{10}$. Thomas and Myers provide substantial commentary on the epistemological status of $\mathrm{CSR}^{3}$, and propose that a way toward understanding and acceptance is to distinguish the 'ideographic' of CSR from the 'nomothetic' of other research approaches $^{3}$. Nomothetic research attempts to establish generalizable principles whereas CSR seeks an ideograph, or a 'picture' of the whole. The epistemological viewpoint and design of CSR will vary depending on the phenomenon to be studied and the researcher's experience and perspective. Accordingly, it is likely the researcher will adopt an approach advocated by CSR exponents who have a similar epistemological stance.

Contemporary proponents of CSR have shifted from valuing a foundation of theory to phronesis, a type of wisdom or intelligence relevant to practical things. In this reframing of CSR, the critical contribution of the researcher is to learn from the experience of others in 
Improving case study research in medical education: Systematised review

the field of inquiry, carefully reflect to integrate ideas, and consider the topic from a novel angle ${ }^{11}$. The study cannot be replicated as each researcher and reader may view the findings differently from a personal perspective; they may each learn something different from it ${ }^{3,5,8}$.

\section{Attributes of good CSR}

Case study is a research approach, rather than a uniform methodology. The approach is used to guide holistic investigation of a real phenomenon in order to advance our knowledge of a broader theme. Often social situations are complex and may consist of many interwoven elements that operate in synergy. An assorted set of methods or data sources may align with the research question and the situation to provide depth of understanding, illuminating features that may have otherwise remained latent. To advance beyond purely description, the researcher must analyse what is interesting about the case. Drawing on the experience and wisdom imparted by participants and the researcher's ability to engage coherently with wider theories, emerging ideas are connected to stimulate the readers' conceptual insight and communicate utility 3, 5, 8,11. Stated more clearly, a case study is in no way a sample to be considered representative of a wider population, but a particular representation of a phenomenon which may provide insight into underlying patterns, processes, conditions and mechanisms. The most important attributes are the thought and analysis refracted in a narrative that weaves together questions and discovery, recognition and intuition, challenges assumptions and references the particular ${ }^{3}$. Proof may not be possible, but the 'imperative of understanding' may be more valuable than proof ${ }^{12}$, allowing new research questions embedded in a conceptual framing to be derived from carefully analysed CSR ${ }^{13}$. In this way learning from CSR may be transferred to the reader's own situation ${ }^{6}$.

As there are various ways that CSR is constructed peer-reviewers may have difficulty assessing CSR for publication. To integrate the diverse conceptualisations of CSR, Thomas and Myers (2015) proposed a typology that defines CSR as one of two parts, subject and object $^{3}$ :

- The subject, or the case itself, may be a (local) knowledge case, an unusual (outlier) case, or a revealing (key) case. 
Improving case study research in medical education: Systematised review

- The object is the analytical frame through which the subject is described.

Thomas and Myers (2015) emphasise careful selection of the two parts, arguing it is the alignment between the subject (case), as an instance of a class, and the object, or way that the subject is scrutinised, that is at the heart of robust CSR ${ }^{3}$. While the object may emerge as the inquiry progresses, there is generally an object in mind at the outset. The object incorporates the purpose, approach and process of the case study:

- The purpose, or reason for doing the study, integrates Stake's terms 'intrinsic' and 'instrumental' 2 , and 'evaluative' or 'exploratory' used by Bassey ${ }^{1}$ and Yin ${ }^{4}$.

- The approach establishes a theoretical basis at the outset with an aim to test or build on theory, or the approach may be entirely descriptive (atheoretical).

- The process is either:

o a single-case study design as one with no comparative analysis, which may be studied retrospectively in a defined period of time (snapshot), or one which describes change over a period of time (diachronic).

o a multiple-case design incorporates embedded units of analysis within a single-case design (nested), one or more comparative analyses occurring at the same time (parallel), or where they are happening consecutively and the outcome of one (or the time in between) may affect the other (sequential).

While this structure may not be in common use, in integrating the different themes and classifications of CSR, we proposed that it would provide a useful framework for reviewing how CSR is reported in the medical education literature. In this study we undertook a review of how CSR articles have been structured and reported in scholarly medical education journals over the last 10 years. We aimed to describe how CSR has been used and how more consistency might be achieved to promote understanding and value.

\section{Methods}

A systematized literature review incorporated a systematic search strategy with a tabulated analysis given that there was no common outcome measurement to synthesise ${ }^{14}$. A modified Population, Interest, Context (PICo) review protocol was formulated collaboratively with all authors. As a literature review, ethics approval was not required. 
Improving case study research in medical education: Systematised review

\section{Eligibility criteria}

\section{Population}

We included in the search all peer-reviewed articles published in scholarly journals from January 2006 to February 2017 that reported primary research of a medical education topic using CSR. This excluded non peer-reviewed articles, books, letters, reports, editorials, perspectives, grey literature; and theses. From the resulting search, we excluded articles where the CSR methods were not discernible, articles where English translation was not available, or where the full text was not available through our library subscriptions.

Interest

CSR was defined as a description of a contemporary event studied in its real-world context, using multiple data sources and/or multiple methods of data collection.

\section{Context}

Medical education was defined as a study undertaken at a medical school or other medical training facility including hospitals, or the subject concerned teaching and learning of medical doctors.

\section{Search Strategy}

A limited search of PubMed, ERIC, and CINAHL was undertaken using the initial key words "case study", "medical education", and additional key words identified from the title and abstract and index terms. A second search was undertaken using all key words identified across PubMed, ERIC, CINAHL, and Informit (Table 1).

\section{Study selection}

After automatic and manual removal of duplicate records, one reviewer (CC) screened the title and abstracts of papers against the eligibility criteria, removing non-medical education, non peer-reviewed, and non-case studies. Full-text papers were retrieved for the remaining papers for more detailed analysis against the eligibility criteria.

A random $10 \%$ sample of included, and excluded articles that explicitly called the study 'case study' was 'double' reviewed blind by each of the other authors (RH, PA, JS). That is, three 
Improving case study research in medical education: Systematised review

mutually exclusive $10 \%$ samples of included and of excluded articles meant $30 \%$ of included and $30 \%$ of excluded articles were reviewed twice. The agreement rate of $88.9 \%$ was resolved to $100 \%$ after discussion but did not result in any additional articles included.

\section{Data abstraction}

For each study the author, year, title, and journal, were recorded, and the CSR design according to the typology proposed by Thomas and Myers (2015) was abstracted from the article.

\section{Results}

The search strategy identified 1,197 separate articles (Figure 1). Of the 377 articles assessed, 12 were excluded as the full text was not available, and 3 had no readily available English translation. Of the remaining 362 full-text articles, 290 were excluded as they did not meet the eligibility criteria - they did not describe research methods at all, used one data source or one method (eg qualitative interviews at one time-point of one participant group in a 'single-case study' design). Of these 290 exclusions, 76 contained 'case study' in the article title.

Among the 72 articles included in the review, 10 papers report findings from 4 overarching studies: 3 papers by Rodriguez et al, 1 paper by Lopez-Roig; 2 papers by Van Hoof et al.; 2 papers by Maggio et al; and 2 papers by Preston et al (Appendix 1 ).

The articles reviewed utilised a CSR approach for a diverse range of topics (Appendix 1). While there was also variety in the design and object of the study, we were able to apply the typology proposed to integrate the range of articles. Most used a single-case design (68\%), reported a local case (61\%), and were purely exploratory (71\%) (Table 2). In spite of the eligibility criteria used to screen articles there remained ambiguity in the design, subject and process. In one article it was not evident whether it was a single or multiple case design. In one article, the object of analysis was determined but neither the subject nor the process were evident. Where the single-case or multiple-case design was unclear it was more difficult to determine how the object was analysed. 
Improving case study research in medical education: Systematised review

The CSR articles in which the structure and design elements were most clearly reported were Skipper et al (2016), Struwig et al (2016), Lund et al (2016), Jippes et al (2013), Isaranuwatchai et al (2014), and Christensen et al (2014).

\section{Discussion}

In this review more articles titled 'case study' did not meet the eligibility criteria than articles that did meet the eligibility criteria. Case study research (CSR) is reported in academic medical education journals on diverse topics such as teaching medical microbiology, socially accountable medical schools, successful research education, the impact of culture and context on curriculum change, and the cost effectiveness of simulation. Despite CSR's popularity, we found ambiguity in design, subject, and process.

In medicine, the term 'case study' is variously used: as a mock clinical scenario for teaching purposes; to report an interesting clinical presentation; and to report CSR. While all are acceptable uses of the term, the rules surrounding the construction of a 'case study' in each context may be different, and they may or may not have any foundation in research. For example, an educational case study may be modified to enhance learning, but manipulation of facts in research is prohibited; a case study of a clinical presentation is often a narrative description and may not include research methods, whereas CSR requires intentional design and justified research methods. Further confusion may surround the divergence of a CSR approach from other research approaches. In this review the term 'case study' was sometimes incorrectly used to describe a non-CSR approach in single-site studies and/or small sample sizes. Blurring of the different uses of the term 'case study' may be contributing to CSR being poorly understood and poorly reported.

Quality criteria have been defined for reporting other research approaches, but quality criteria do not appear to be consistently applied to reporting CSR. Academic audiences must feel satisfied with the integrity of the study and that the claims being made are supported by the evidence ${ }^{4,5}$. Perhaps because of the extent of data collected and the need to limit content to prescribed journal formats, some articles in this study reported findings from only one of the collection methods used. Care needs to be taken that the 
Improving case study research in medical education: Systematised review

holistic nature that is the essence of CSR is not lost in carving out publishable sections. If this is the preferred format for reporting though, it should no longer be described as CSR.

The typology provided a useful framework to understand the structure of the reviewed articles, which were based on various conceptual models. Thomas and Myers warn against being rigidly obsessed with exactitude of design and reliability at the expense of imagination and intuition ${ }^{3}$. In order to enhance the quality of CSR in academic publications we propose clear description of:

- the contemporary phenomenon (subject) or instance to be studied in its real world setting;

- the analytical frame (object) or aspect of the phenomenon to be explained, including the purpose, approach, and process;

- $\quad$ the single-case or multiple-case design and embedded units of analysis where relevant;

- methods that are congruent with the object; and

- multiple methods or multiple data sources used to achieve rich description, should this be relevant to the purpose and available data.

Consistent and thoughtful construction and a commitment to extract relevant and meaningful information rather than simply writing up a description might promote CSR as a valuable method of inquiry and increase the impact of findings.

\section{Limitations}

The number of articles reviewed was limited by the search strategy and eligibility criteria. Only studies published in English were included; while this resulted in only three articles excluded from those selected through the search criteria, articles published in other languages could also have been important to this review. It was not feasible to include books and theses in this review, but there may be value in including a broader range of literature in further research to capture more detailed CSR reports. Nevertheless, we included articles that complied with the accepted definition of CSR and contained sufficient description of methods to allow extrapolation to the framework. While the framework may 
Improving case study research in medical education: Systematised review

not yet be widely used, it may be useful in communicating the key ingredients of good CSR regardless of the epistemological viewpoint of the researcher.

\section{Conclusion}

Well-structured, clearly written CSR in medical education has the potential to increase understanding of more complex situations through critical analysis and clarification of contributing factors, challenge to assumptions, and guidance for 'intelligent action' that may have relevance more broadly. A review of CSR in medical education over the last 10 years shows considerable variation in how it is conducted, potentially limiting its value in translation into educational practice. Case study research (CSR) may be of more value in medical education if researchers more consistently followed principles of design and reporting as outlined in this paper. Research frameworks for CSR are available, and their application may reduce ambiguity and enhance the value and transferability of output.

\section{References}

[1] Bassey M. Case study research in educational settings. 1999.

[2] Stake RE. Qualitative case studies. 2005.

[3] Thomas G, Myers K. The anatomy of the case study. Sage; 2015 May 20. ISBN: 978-14462-4863-8.

[4] Yin RK. Case study research: Design and methods Sage publications; 2013.

[5] Harland T. Learning about case study methodology to research higher education. Higher Education Research \& Development. 2014;33:1113-1122.

[6] Flyvbjerg B. Five misunderstandings about case-study research. Qualitative inquiry. 2006;12:219-245.

[7] Elliott J. Validating case studies. Westminster Studies in Education. 1990;13:47-60.

[8] Verschuren P. Case study as a research strategy: some ambiguities and opportunities. International Journal of Social Research Methodology. 2003;6:121139.

[9] Creswell JW. Qualitative inquiry and research design: Choosing among five approaches Sage publications; 2012.

[10] Gerring J. What is a case study and what is it good for? American Political Science Review, 98(2): 341-54.

[11] Tight M. The curious case of case study: a viewpoint. International Journal of Social Research Methodology. 2010;13:329-339.

[12] Regehr G. It's NOT rocket science: rethinking our metaphors for research in health professions education. Medical Education. 2010;44(1):31-39.

[13] Bordage G. Conceptual frameworks to illuminate and magnify. Medical Education. 2009;43(4):312-319.

[14] Grant MJ, Booth A. A typology of reviews: an analysis of 14 review types and associated methodologies. Health Information \& Libraries Journal. 2009;26:91-108. 
Improving case study research in medical education: Systematised review

\section{Tables and Figures}

Table 1-Search terms and number of results for review of Case Study Research in medical education journals (Filters: Publication date from 2006/01/01 to 2017/02/13)

\begin{tabular}{|c|l|r|}
\hline Database & Search query & Results, $n$ \\
\hline PubMed & $\begin{array}{l}\text { Search (Medical education[Title/Abstract] OR Medical } \\
\text { school[Title/Abstract] OR medical train*[Title/Abstract] OR } \\
\text { academic medicine[Title/Abstract] OR medical } \\
\text { curricul*[Title/Abstract] OR medical student[Title/Abstract]) AND } \\
\text { case study[Text Word] }\end{array}$ & 239 \\
\hline CINAHL & $\begin{array}{l}\text { ((AB Medical education) OR (AB academic medicine) OR (AB } \\
\text { medical curriculum ) OR (AB medical school*) OR (AB medical } \\
\text { student*) OR (AB medical train*)) AND TX case study }\end{array}$ & 768 \\
\hline InformIT & $\begin{array}{l}\text { ((AB Medical education) OR (AB academic medicine) OR (AB } \\
\text { medical curriculum ) OR (AB medical school*) OR (AB medical } \\
\text { student*) OR (AB medical train*)) AND TX case study }\end{array}$ & $\begin{array}{l}\text { (AB:Culum } \\
\text { AB:student*) OR (AB:medical AB:school*)) AND } \\
\text { (ALLTERMS,FC:"case study") }\end{array}$ \\
\hline
\end{tabular}


Improving case study research in medical education: Systematised review

Table 2 - Structure of case study research in articles reviewed from medical education journals 2006 - 2017

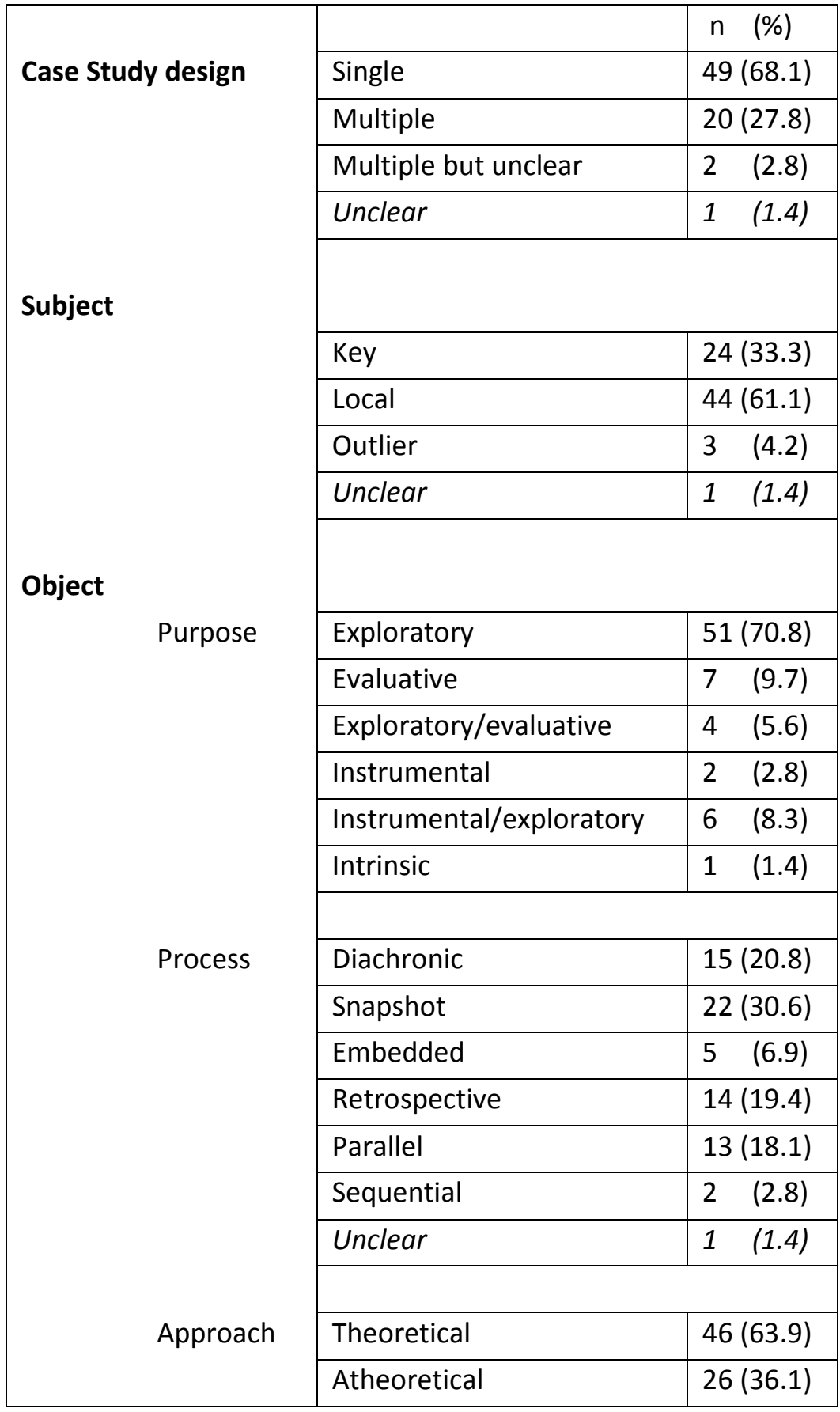




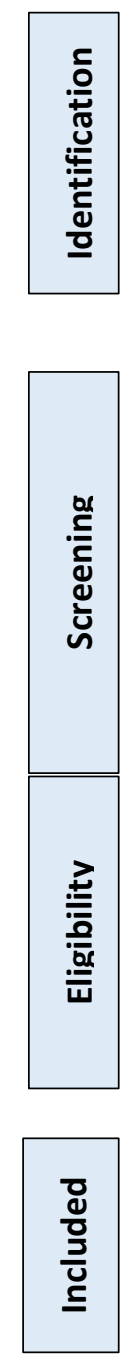

$$
\begin{aligned}
& \text { Records identified through } \\
& \text { database searches (with removal of } \\
& \text { duplicates) } n=1197
\end{aligned}
$$

Records screened for medical

education content $\mathrm{n}=1197$

Records excluded $n=451$

Records excluded $n=369$

Abstracts screened $\mathrm{n}=746$

Records excluded $\mathrm{n}=305$

Full text articles assessed $n=377$

(includes 76 with 'case

study' in the title)

Full text articles included $n=72$

Figure 1 - PRISMA diagram of systematised review of case study research in medical education journals 2006 - 2017 


\section{Appendix}

Table 2 - Case Study Research articles reviewed and tabulated using Thomas and Myers (2015) typology ${ }^{3}$

\begin{tabular}{|c|c|c|c|c|c|c|c|c|}
\hline \multirow[b]{2}{*}{ Article } & \multirow{2}{*}{$\begin{array}{l}\text { Case } \\
\text { Study } \\
\text { Design }\end{array}$} & \multicolumn{2}{|l|}{ Subject } & \multicolumn{5}{|l|}{ Object } \\
\hline & & $\begin{array}{l}\text { Instance - the } \\
\text { 'case' }\end{array}$ & $\begin{array}{l}\text { Key, } \\
\text { local, } \\
\text { outlier }\end{array}$ & $\begin{array}{l}\text { unit of analysis/to } \\
\text { be explained }\end{array}$ & Purpose & Process & Approach & Methods \\
\hline $\begin{array}{l}\text { Bac, M., et al. (2015). "Medical education } \\
\text { and the quality improvement spiral: A } \\
\text { case study from Mpumalanga, South } \\
\text { Africa." Afr J Prim Health Care Fam Med } \\
\text { 7(1). }\end{array}$ & single & $\begin{array}{l}\text { Quality } \\
\text { improvement in } \\
\text { medical education - } \\
\text { the Mother- and } \\
\text { Baby-Friendly } \\
\text { initiative (MBFI) }\end{array}$ & local & $\begin{array}{l}\text { the process of } \\
\text { inducting students } \\
\text { into a longitudinal } \\
\text { Ql project }\end{array}$ & exploratory & diachronic & theoretical & $\begin{array}{l}\text { qualitative - } \\
\text { document review, } \\
\text { OSCE notes, student } \\
\text { reports }\end{array}$ \\
\hline $\begin{array}{l}\text { Balmer, D. F., et al. (2015). "How Students } \\
\text { Experience and Navigate Transitions in } \\
\text { Undergraduate Medical Education: An } \\
\text { Application of Bourdieu's Theoretical } \\
\text { Model." Advances in Health Sciences } \\
\text { Education 20(4): 1073-1085. }\end{array}$ & single & $\begin{array}{l}\text { One medical } \\
\text { student cohort's } \\
\text { experience of } \\
\text { transition from } \\
\text { preclinical, to major } \\
\text { clinical, to } \\
\text { preparation for } \\
\text { residency }\end{array}$ & local & $\begin{array}{l}\text { Navigating } \\
\text { transitions } \\
\text { between medical } \\
\text { school and the } \\
\text { health system } \\
\text { during medical } \\
\text { training }\end{array}$ & exploratory & diachronic & theoretical & $\begin{array}{l}\text { qualitative - semi- } \\
\text { structured } \\
\text { interviews, thematic } \\
\text { analysis and theory- } \\
\text { informed cluster }\end{array}$ \\
\hline $\begin{array}{l}\text { Balmer, D. F., et al. (2008). } \\
\text { "Understanding paediatric resident- } \\
\text { continuity preceptor relationships through } \\
\text { the lens of apprenticeship learning." Med } \\
\text { Educ 42(9): } 923-929 .\end{array}$ & single & $\begin{array}{l}\text { Apprenticeship } \\
\text { learning in a } \\
\text { community-based } \\
\text { paediatric resident } \\
\text { training }\end{array}$ & local & $\begin{array}{l}\text { Preceptor } \\
\text { relationships in } \\
\text { medical education }\end{array}$ & exploratory & diachronic & theoretical & $\begin{array}{l}\text { ethnography, } \\
\text { qualitative - } \\
\text { interviews and } \\
\text { observation, } \\
\text { thematic analysis }\end{array}$ \\
\hline $\begin{array}{l}\text { Bardach, S. H. and G. D. Rowles (2012). } \\
\text { "Geriatric Education in the Health } \\
\text { Professions: Are We Making Progress?" } \\
\text { Gerontologist 52(5): 607-618. }\end{array}$ & single & $\begin{array}{l}\text { curricula in health } \\
\text { professions } \\
\text { education } \\
\text { programs }\end{array}$ & local & $\begin{array}{l}\text { Geriatric education } \\
\text { in health } \\
\text { professions } \\
\text { education }\end{array}$ & exploratory & snapshot & atheoretical & $\begin{array}{l}\text { qualitative - } \\
\text { interviews, constant } \\
\text { comparative analysis }\end{array}$ \\
\hline
\end{tabular}


Improving case study research in medical education: Systematised review

\begin{tabular}{|c|c|c|c|c|c|c|c|c|}
\hline $\begin{array}{l}\text { Barnett, S., et al. (2014). "Implementing a } \\
\text { virtual community of practice for family } \\
\text { physician training: a mixed-methods case } \\
\text { study." Journal of Medical Internet } \\
\text { Research 16(3): e83-e83. }\end{array}$ & single & $\begin{array}{l}\text { A virtual } \\
\text { community of } \\
\text { practice for GP } \\
\text { training }\end{array}$ & local & $\begin{array}{l}\text { Experience of } \\
\text { General Practice } \\
\text { trainees }\end{array}$ & $\begin{array}{l}\text { exploratory, } \\
\text { evaluative }\end{array}$ & snapshot & theoretical & $\begin{array}{l}\text { mixed methods - } \\
\text { survey and } \\
\text { interviews }\end{array}$ \\
\hline $\begin{array}{l}\text { Beaulieu, M., et al. (2008). "Family } \\
\text { practice: professional identity in } \\
\text { transition. A case study of family medicine } \\
\text { in Canada." Social Science \& Medicine } \\
67(7): 1153-1163 .\end{array}$ & multiple & $\begin{array}{l}\text { Academic and } \\
\text { medical student } \\
\text { perceptions of the } \\
\text { role of family } \\
\text { medicine at } 4 \\
\text { medical schools - } 2 \\
\text { with primary care } \\
\text { orientation, } 2 \text { with } \\
\text { specialty } \\
\text { orientation }\end{array}$ & local & $\begin{array}{l}\text { Professional } \\
\text { identity of Family } \\
\text { Practice in Canada }\end{array}$ & exploratory & embedded & theoretical & $\begin{array}{l}\text { qualitative - } \\
\text { interviews Educators } \\
\text { and residents }\end{array}$ \\
\hline $\begin{array}{l}\text { Brown, C., et al. (2015). "Money makes } \\
\text { the (medical assessment) world go round: } \\
\text { The cost of components of a summative } \\
\text { final year Objective Structured Clinical } \\
\text { Examination (OSCE)." Med Teach: 1-7. }\end{array}$ & single & $\begin{array}{l}\text { financial costs of } \\
\text { OSCE at one } \\
\text { medical school }\end{array}$ & local & $\begin{array}{l}\text { Cost of assessment } \\
\text { in medical } \\
\text { education }\end{array}$ & evaluative & retrospective & atheoretical & $\begin{array}{l}\text { quantative - financial } \\
\text { costs }\end{array}$ \\
\hline $\begin{array}{l}\text { Campos, J. J., et al. (2009). "Teaching } \\
\text { public health in undergraduate medical } \\
\text { courses: a case study in three universities } \\
\text { in Parana." Sao Paulo Med J 127(6): 335- } \\
341 .\end{array}$ & multiple & $\begin{array}{l}\text { The structure of } \\
\text { public health } \\
\text { educational } \\
\text { curricula of three } \\
\text { medical schools }\end{array}$ & local & $\begin{array}{l}\text { Public health within } \\
\text { undergraduate } \\
\text { medical training in } \\
\text { Brazil }\end{array}$ & exploratory & parallel & theoretical & $\begin{array}{l}\text { qualitative - } \\
\text { interviews, } \\
\text { document review }\end{array}$ \\
\hline $\begin{array}{l}\text { Casey, M. G., et al. (2015). "Diversity and } \\
\text { consistency: a case study of regionalised } \\
\text { clinical placements for medical students." } \\
\text { Aust Health Rev 39(1): } 95-100 .\end{array}$ & single & $\begin{array}{l}\text { Achievement of } \\
\text { education } \\
\text { standards (AQF) } \\
\text { across a regional } \\
\text { clinical teaching } \\
\text { network }\end{array}$ & local & $\begin{array}{l}\text { clinical skills } \\
\text { training in medical } \\
\text { schools }\end{array}$ & evaluative & retrospective & atheoretical & quantative \\
\hline $\begin{array}{l}\text { Christensen, M. K. and O. Lund (2014). } \\
\text { "Doctoral Education in a Successful } \\
\text { Ecological Niche: A Qualitative Exploratory } \\
\text { Case Study of the Relationship between } \\
\text { the Microclimate and Doctoral Students' } \\
\text { Learning to Become a Researcher." } \\
\text { International Journal of Higher Education } \\
\text { 3(3): 103-113. }\end{array}$ & single & $\begin{array}{l}\text { The microclimate in } \\
\text { an ecological niche } \\
\text { of doctoral } \\
\text { education }\end{array}$ & key & $\begin{array}{l}\text { Successful doctoral } \\
\text { education in } \\
\text { medical education }\end{array}$ & exploratory & snapshot & theoretical & qualitative interviews \\
\hline
\end{tabular}


Improving case study research in medical education: Systematised review

\begin{tabular}{|c|c|c|c|c|c|c|c|c|}
\hline $\begin{array}{l}\text { Clark, M. L., et al. (2010). "Musculoskeletal } \\
\text { education: a curriculum evaluation at one } \\
\text { university." BMC Med Educ 10: } 93 \text {. }\end{array}$ & single & $\begin{array}{l}\text { Undergraduate } \\
\text { musculoskeletal } \\
\text { curriculum at one } \\
\text { medical school }\end{array}$ & local & $\begin{array}{l}\text { Strengths and } \\
\text { weaknesses of } \\
\text { musculoskeletal } \\
\text { education in } \\
\text { medical schools }\end{array}$ & exploratory & retrospective & theoretical & $\begin{array}{l}\text { mixed methods - } \\
\text { document review, } \\
\text { MCQ exams, } \\
\text { evaluation data, } \\
\text { interviews }\end{array}$ \\
\hline $\begin{array}{l}\text { Corwin, S. J., et al. (2007). "Two Models } \\
\text { for Implementing Senior Mentor Programs } \\
\text { in Academic Medical Settings." } \\
\text { Educational Gerontology 33(5): 383-393. }\end{array}$ & multiple & $\begin{array}{l}\text { senior mentoring } \\
\text { programs in two } \\
\text { medical settings }\end{array}$ & local & $\begin{array}{l}\text { geriatric education } \\
\text { in medical schools }\end{array}$ & exploratory & $\begin{array}{l}\text { parallel } \\
\text { (retrospective) }\end{array}$ & atheoretical & $\begin{array}{l}\text { qualitative - } \\
\text { document review, } \\
\text { interview, focus } \\
\text { groups }\end{array}$ \\
\hline $\begin{array}{l}\text { Cresswell, K., et al. (2013). "Patient safety } \\
\text { in healthcare preregistration educational } \\
\text { curricula: multiple case study-based } \\
\text { investigations of eight medicine, nursing, } \\
\text { pharmacy and physiotherapy university } \\
\text { courses." BMJ Qual Saf 22(10): 843-854. }\end{array}$ & multiple & $\begin{array}{l}\text { Patient safety } \\
\text { knowledge taught } \\
\text { in } 8 \text { healthcare } \\
\text { professional } \\
\text { preregistration } \\
\text { university courses }\end{array}$ & local & $\begin{array}{l}\text { Learning about } \\
\text { patient safety }\end{array}$ & exploratory & parallel & theoretical & $\begin{array}{l}\text { qualitative - } \\
\text { document review, } \\
\text { observations, focus } \\
\text { groups, interviews }\end{array}$ \\
\hline $\begin{array}{l}\text { Duffy, M. C., et al. (2015). "Team } \\
\text { Regulation in a Simulated Medical } \\
\text { Emergency: An In-Depth Analysis of } \\
\text { Cognitive, Metacognitive, and Affective } \\
\text { Processes." Instructional Science: An } \\
\text { International Journal of the Learning } \\
\text { Sciences 43(3): 401-426. }\end{array}$ & single & $\begin{array}{l}\text { Medical team } \\
\text { performance during } \\
\text { a simulated medical } \\
\text { emergency }\end{array}$ & key & $\begin{array}{l}\text { cognitive, affective } \\
\text { and metacognitive } \\
\text { processes affecting } \\
\text { performance }\end{array}$ & $\begin{array}{l}\text { Instrumental } \\
\text {, exploratory }\end{array}$ & snapshot & theoretical & $\begin{array}{l}\text { mixed methods - } \\
\text { recordings of } \\
\text { simulation, de-briefer } \\
\text { ratings, interviews }\end{array}$ \\
\hline $\begin{array}{l}\text { Findyartini, A., et al. (2016). "How clinical } \\
\text { reasoning is taught and learned: Cultural } \\
\text { perspectives from the University of } \\
\text { Melbourne and Universitas Indonesia." } \\
\text { BMC Med Educ 16: } 185 .\end{array}$ & multiple & $\begin{array}{l}\text { medical student } \\
\text { attitudes to clinical } \\
\text { reasoning in } 2 \\
\text { medical schools }\end{array}$ & key & $\begin{array}{l}\text { The influence of } \\
\text { culture of learning } \\
\text { on the teaching and } \\
\text { learning process in } \\
\text { medical training }\end{array}$ & evaluative & parallel & theoretical & $\begin{array}{l}\text { mixed - measure of } \\
\text { diagnostic ability, } \\
\text { focus group, } \\
\text { interview }\end{array}$ \\
\hline $\begin{array}{l}\text { Frambach, J. M., et al. (2014). "Quiet or } \\
\text { Questioning? Students' Discussion } \\
\text { Behaviors in Student-Centered Education } \\
\text { across Cultures." Studies in Higher } \\
\text { Education 39(6): 1001-1021. }\end{array}$ & multiple & $\begin{array}{l}\text { Cross-cultural } \\
\text { applicability of PBL }\end{array}$ & key & $\begin{array}{l}\text { cross-cultural } \\
\text { differences in } \\
\text { communication } \\
\text { styles }\end{array}$ & exploratory & parallel & theoretical & $\begin{array}{l}\text { qualitative - field } \\
\text { work, interviews, }\end{array}$ \\
\hline $\begin{array}{l}\text { Frambach, J. M., et al. (2012). "Rethinking } \\
\text { the globalisation of problem-based } \\
\text { learning: how culture challenges self- } \\
\text { directed learning." Med Educ 46(8): 738- } \\
747 .\end{array}$ & multiple & $\begin{array}{l}\text { Cross-cultural } \\
\text { applicability of PBL }\end{array}$ & key & $\begin{array}{l}\text { How culture and } \\
\text { context impact self- } \\
\text { directed learning }\end{array}$ & exploratory & parallel & theoretical & $\begin{array}{l}\text { qualitative - field } \\
\text { work, interviews, }\end{array}$ \\
\hline
\end{tabular}


Improving case study research in medical education: Systematised review

\begin{tabular}{|c|c|c|c|c|c|c|c|c|}
\hline $\begin{array}{l}\text { Goldszmidt, M., et al. (2014). "Progressive } \\
\text { collaborative refinement on teams: } \\
\text { implications for communication } \\
\text { practices." Med Educ 48(3): 301-314. }\end{array}$ & multiple & $\begin{array}{l}\text { Medical teaching } \\
\text { teams in an internal } \\
\text { medicine ward }\end{array}$ & local & $\begin{array}{l}\text { Communication } \\
\text { practices that } \\
\text { facilitate patient } \\
\text { care }\end{array}$ & instrumental & diachronic & theoretical & $\begin{array}{l}\text { qualitative - } \\
\text { document review, } \\
\text { field notes, case } \\
\text { reviews, focus groups }\end{array}$ \\
\hline $\begin{array}{l}\text { Gray, K., et al. (2010). "Medical students' } \\
\text { use of Facebook to support learning: } \\
\text { Insights from four case studies." Med } \\
\text { Teach 32(12): } 971-976 .\end{array}$ & single & $\begin{array}{l}\text { Facebook use by } \\
\text { medical students at } \\
\text { one university }\end{array}$ & local & $\begin{array}{l}\text { Use of social } \\
\text { networking to } \\
\text { support medical } \\
\text { student learning }\end{array}$ & exploratory & embedded & theoretical & $\begin{array}{l}\text { mixed methods - } \\
\text { survey and 'case } \\
\text { studies' }\end{array}$ \\
\hline $\begin{array}{l}\text { Hayes, A. L., et al. (2015). "Understanding } \\
\text { intercultural transitions of medical } \\
\text { students." Int J Med Educ 6: 26-37. }\end{array}$ & single & $\begin{array}{l}\text { Transition of } \\
\text { students from a } \\
\text { mainstream } \\
\text { Bahraini secondary } \\
\text { school with Arabic } \\
\text { as first language to } \\
\text { an international } \\
\text { branch of an } \\
\text { English-speaking } \\
\text { medical university }\end{array}$ & outlier & $\begin{array}{l}\text { intercultural } \\
\text { transitions of } \\
\text { medical students }\end{array}$ & exploratory & snapshot & theoretical & $\begin{array}{l}\text { qualitative - } \\
\text { interviews, focus } \\
\text { groups }\end{array}$ \\
\hline $\begin{array}{l}\text { Hervatis, V., et al. (2015). "A Conceptual } \\
\text { Analytics Model for an Outcome-Driven } \\
\text { Quality Management Framework as Part } \\
\text { of Professional Healthcare Education." } \\
\text { JMIR Med Educ 1(2): e11. }\end{array}$ & single & unclear & unclear & $\begin{array}{l}\text { Use of data } \\
\text { analytics to support } \\
\text { healthcare } \\
\text { education }\end{array}$ & exploratory & unclear & theoretical & $\begin{array}{l}\text { qualitative - } \\
\text { observations, } \\
\text { interviews }\end{array}$ \\
\hline $\begin{array}{l}\text { Hosny, S., et al. (2015). "Is our medical } \\
\text { school socially accountable? The case of } \\
\text { Faculty of Medicine, Suez Canal } \\
\text { University." Med Teach 37: S47-55. }\end{array}$ & single & $\begin{array}{l}\text { Faculty of } \\
\text { Medicine, Suez } \\
\text { Canal University }\end{array}$ & local & $\begin{array}{l}\text { Evaluating medical } \\
\text { school social } \\
\text { accountability }\end{array}$ & exploratory & retrospective & theoretical & $\begin{array}{l}\text { qualitative - } \\
\text { interviews, } \\
\text { document review }\end{array}$ \\
\hline $\begin{array}{l}\text { Howe, A., et al. (2007). "Patient contact in } \\
\text { the first year of basic medical training-- } \\
\text { feasible, educational, acceptable?" Med } \\
\text { Teach 29(2-3): } 237-245 \text {. }\end{array}$ & single & $\begin{array}{l}\text { medical student- } \\
\text { patient contact in } \\
\text { the first two years } \\
\text { of medical training } \\
\text { at a new medical } \\
\text { school }\end{array}$ & key & $\begin{array}{l}\text { Feasibility of } \\
\text { patient contact in } \\
\text { early clinical } \\
\text { placements }\end{array}$ & exploratory & diachronic & atheoretical & $\begin{array}{l}\text { mixed methods - } \\
\text { questionnaire, focus } \\
\text { groups, interviews, } \\
\text { OSCE examiner } \\
\text { comments, survey } \\
\text { questions }\end{array}$ \\
\hline $\begin{array}{l}\text { Isaranuwatchai, W., et al. (2014). } \\
\text { "Comparing the Cost-Effectiveness of } \\
\text { Simulation Modalities: A Case Study of } \\
\text { Peripheral Intravenous Catheterization } \\
\text { Training." Advances in Health Sciences } \\
\text { Education 19(2): 219-232. }\end{array}$ & single & $\begin{array}{l}\text { Performing IV } \\
\text { cannulation }-3 \\
\text { training programs } \\
\text { of varying fidelity }\end{array}$ & key & $\begin{array}{l}\text { Cost-effectiveness } \\
\text { of simulation } \\
\text { modalities }\end{array}$ & evaluative & snapshot & atheoretical & quantitative \\
\hline
\end{tabular}


Improving case study research in medical education: Systematised review

\begin{tabular}{|c|c|c|c|c|c|c|c|c|}
\hline $\begin{array}{l}\text { Jippes, M., et al. (2013). "Impact of } \\
\text { national context and culture on } \\
\text { curriculum change: A case study." Med } \\
\text { Teach 35(8): 661-670. }\end{array}$ & single & $\begin{array}{l}4 \text { medical schools } \\
\text { who had adopted } \\
\text { integrated medical } \\
\text { curricula in a } \\
\text { country with high } \\
\text { uncertainty } \\
\text { avoidance }\end{array}$ & key & $\begin{array}{l}\text { impact of culture } \\
\text { and context on } \\
\text { curriculum change } \\
\text { in medical } \\
\text { education }\end{array}$ & exploratory & snapshot & theoretical & $\begin{array}{l}\text { qualitative - } \\
\text { interviews, } \\
\text { document review }\end{array}$ \\
\hline $\begin{array}{l}\text { Kilminster, S., et al. (2011). "Preparedness } \\
\text { is not enough: understanding transitions } \\
\text { as critically intensive learning periods." } \\
\text { Med Educ 45(10): 1006-1015. }\end{array}$ & $\begin{array}{l}\text { multiple } \\
\text { - unclear }\end{array}$ & $\begin{array}{l}\text { Experiences of } \\
\text { Junior (Y1) and } \\
\text { specialists doctors } \\
\text { at } 6 \text { sites } \\
\text { transitioning into } \\
\text { complex work } \\
\text { settings }\end{array}$ & local & $\begin{array}{l}\text { Effects of } \\
\text { transitions during } \\
\text { medical training on } \\
\text { medical } \\
\text { performance }\end{array}$ & exploratory & snapshot & theoretical & $\begin{array}{l}\text { qualitative - } 6 \text { study } \\
\text { hospitals - } \\
\text { interviews, } \\
\text { document review, } \\
\text { observation }\end{array}$ \\
\hline $\begin{array}{l}\text { Leung, K. H., et al. (2010). "A Reflective } \\
\text { Learning Framework to Evaluate CME } \\
\text { Effects on Practice Reflection." Journal of } \\
\text { Continuing Education in the Health } \\
\text { Professions 30(2): 78-88. }\end{array}$ & multiple & $\begin{array}{l}\text { One instance of } \\
\text { Reflective Learning } \\
\text { Framework ( } 2029 \\
\text { cases) }\end{array}$ & local & $\begin{array}{l}\text { Validation of a } \\
\text { Reflective Learning } \\
\text { Framework }\end{array}$ & evaluative & diachronic & atheoretical & $\begin{array}{l}\text { interviews, } \\
\text { comments (unclear } \\
\text { as uses results of } \\
\text { separately reported } \\
\text { study as another } \\
\text { method) }\end{array}$ \\
\hline $\begin{array}{l}\text { Lopez-Roig, S., et al. (2010). "The } \\
\text { reputation and professional identity of } \\
\text { family medicine practice according to } \\
\text { medical students: a Spanish case study." } \\
\text { Aten Primaria 42(12): 591-601. }\end{array}$ & single & $\begin{array}{l}\text { Medical student } \\
\text { perceptions of } \\
\text { family medicine at } \\
\text { a medical school in } \\
\text { Spain }\end{array}$ & local & $\begin{array}{l}\text { Reputation and } \\
\text { professional } \\
\text { identity of Family } \\
\text { Medicine }\end{array}$ & exploratory & diachronic & theoretical & $\begin{array}{l}\text { qualitative - focus } \\
\text { groups, document } \\
\text { analysis }\end{array}$ \\
\hline $\begin{array}{l}\text { Lu, J., et al. (2010). "Scaffolding Problem- } \\
\text { Based Learning with CSCL Tools." } \\
\text { International Journal of Computer- } \\
\text { Supported Collaborative Learning 5(3): } \\
\text { 283-298. }\end{array}$ & single & $\begin{array}{l}\text { teacher scaffolding } \\
\text { using interactive } \\
\text { whiteboard and } \\
\text { traditional } \\
\text { whiteboard }\end{array}$ & local & $\begin{array}{l}\text { Use of technology } \\
\text { to facilitate } \\
\text { problem-based } \\
\text { learning }\end{array}$ & exploratory & sequential & theoretical & $\begin{array}{l}\text { qualitative - role play } \\
\text { recordings - thematic } \\
\text { analysis, content } \\
\text { analysis }\end{array}$ \\
\hline $\begin{array}{l}\text { Lund, O., et al. (2016). "Old habits die } \\
\text { hard: a case study on how new ways of } \\
\text { teaching colonoscopy affect the habitus of } \\
\text { experienced clinicians." Int J Med Educ 7: } \\
\text { 297-308. }\end{array}$ & single & $\begin{array}{l}\text { Specialised training } \\
\text { program for a } \\
\text { colonoscopy } \\
\text { service }\end{array}$ & key & $\begin{array}{l}\text { Training the expert } \\
\text { clinician to teach }\end{array}$ & $\begin{array}{l}\text { instrumental } \\
\text {, exploratory }\end{array}$ & diachronic & theoretical & $\begin{array}{l}\text { Qualitative - } \\
\text { interviews and field } \\
\text { notes }\end{array}$ \\
\hline $\begin{array}{l}\text { Luu, N. H., et al. (2009). "Motivation of } \\
\text { university and non-university stakeholders } \\
\text { to change medical education in Vietnam." } \\
\text { BMC Med Educ 9: } 49 .\end{array}$ & single & $\begin{array}{l}\text { community- } \\
\text { involved curriculum } \\
\text { design }\end{array}$ & local & $\begin{array}{l}\text { Stakeholder } \\
\text { motivation to } \\
\text { change }\end{array}$ & exploratory & diachronic & atheoretical & qualitative \\
\hline
\end{tabular}


Improving case study research in medical education: Systematised review

\begin{tabular}{|c|c|c|c|c|c|c|c|c|}
\hline $\begin{array}{l}\text { Maggio, L. A. (2016). "Educating } \\
\text { physicians in evidence based medicine: } \\
\text { current practices and curricular } \\
\text { strategies." Perspect Med Educ 5(6): 358- } \\
361 .\end{array}$ & multiple & $\begin{array}{l}\text { Teaching and } \\
\text { learning EBM in } \\
\text { medical schools }\end{array}$ & local & $\begin{array}{l}\text { Challenges faced by } \\
\text { instructors and } \\
\text { strategies used to } \\
\text { teach EBM s in } \\
\text { medical schools }\end{array}$ & exploratory & parallel & atheoretical & $\begin{array}{l}\text { qualitative - } \\
\text { interviews, } \\
\text { document review }\end{array}$ \\
\hline $\begin{array}{l}\text { Maggio, L. A., et al. (2016). "Challenges to } \\
\text { Learning Evidence-Based Medicine and } \\
\text { Educational Approaches to Meet These } \\
\text { Challenges: A Qualitative Study of } \\
\text { Selected EBM Curricula in U.S. and } \\
\text { Canadian Medical Schools." Acad Med } \\
\text { 91(1): 101-106. }\end{array}$ & multiple & $\begin{array}{l}\text { Teaching and } \\
\text { learning EBM in } \\
\text { medical schools }\end{array}$ & local & $\begin{array}{l}\text { Challenges faced by } \\
\text { instructors and } \\
\text { strategies used to } \\
\text { teach EBM s in } \\
\text { medical schools }\end{array}$ & exploratory & parallel & atheoretical & $\begin{array}{l}\text { qualitative - } \\
\text { interviews, } \\
\text { document review }\end{array}$ \\
\hline $\begin{array}{l}\text { Muir, F. and S. Law (2014). "Students' } \\
\text { perceptions and experiences of a new } \\
\text { "Teaching in Medicine" BMSc intercalated } \\
\text { degree programme." Med Teach 36(5): } \\
\text { 403-408. }\end{array}$ & single & $\begin{array}{l}\text { student } \\
\text { experiences of a } \\
\text { BMSc Teaching in } \\
\text { Medicine } \\
\text { Intercalated degree } \\
\text { programme at a } \\
\text { university } \\
\end{array}$ & local & $\begin{array}{l}\text { Intercalated } \\
\text { medical degree } \\
\text { programs }\end{array}$ & exploratory & snapshot & atheoretical & $\begin{array}{l}\text { qualitative - } \\
\text { interview and } \\
\text { questionnaire }\end{array}$ \\
\hline $\begin{array}{l}\text { Muntinga, M. E., et al. (2016). "Toward } \\
\text { Diversity-Responsive Medical Education: } \\
\text { Taking an Intersectionality-Based } \\
\text { Approach to a Curriculum Evaluation." } \\
\text { Advances in Health Sciences Education } \\
\text { 21(3): 541-559. }\end{array}$ & single & $\begin{array}{l}\text { Diversity-related } \\
\text { learning objectives } \\
\text { and integration of } \\
\text { diversity into a } \\
\text { medical school } \\
\text { curriculum } \\
\end{array}$ & local & $\begin{array}{l}\text { Diversity - } \\
\text { responsive medical } \\
\text { curricula }\end{array}$ & $\begin{array}{l}\text { exploratory, } \\
\text { evaluative }\end{array}$ & retrospective & theoretical & $\begin{array}{l}\text { qualitative - } \\
\text { interviews, } \\
\text { document review, } \\
\text { observation }\end{array}$ \\
\hline $\begin{array}{l}\text { Nestel, D., et al. (2011). "Implementation } \\
\text { of a multi-level evaluation strategy: a case } \\
\text { study on a program for international } \\
\text { medical graduates." J Educ Eval Health } \\
\text { Prof 8: } 13 .\end{array}$ & single & $\begin{array}{l}\text { Evaluation strategy } \\
\text { for an educational } \\
\text { intervention to } \\
\text { support } \\
\text { international } \\
\text { medical graduates }\end{array}$ & local & $\begin{array}{l}\text { Evaluation of } \\
\text { educational } \\
\text { interventions }\end{array}$ & evaluative & diachronic & theoretical & $\begin{array}{l}\text { mixed methods - } \\
\text { interviews, workshop } \\
\text { evaluation, website } \\
\text { usage stats, }\end{array}$ \\
\hline $\begin{array}{l}\text { Ong, C. C., et al. (2016). "Beliefs and } \\
\text { values about intra-operative teaching and } \\
\text { learning: a case study of surgical teachers } \\
\text { and trainees." Adv Health Sci Educ Theory } \\
\text { Pract 21(3): 587-607. }\end{array}$ & multiple & $\begin{array}{l}\text { Intra-operative } \\
\text { teaching and } \\
\text { learning }\end{array}$ & local & $\begin{array}{l}\text { Beliefs and values } \\
\text { of teachers and } \\
\text { trainees }\end{array}$ & exploratory & parallel & theoretical & $\begin{array}{l}\text { qualitative - } \\
\text { interviews and } \\
\text { independent } \\
\text { observation }\end{array}$ \\
\hline
\end{tabular}


Improving case study research in medical education: Systematised review

\begin{tabular}{|c|c|c|c|c|c|c|c|c|}
\hline $\begin{array}{l}\text { Parry, J., et al. (2008). "More students, } \\
\text { less capacity? An assessment of the } \\
\text { competing demands on academic medical } \\
\text { staff." Med Educ 42(12): 1155-1165. }\end{array}$ & multiple & $\begin{array}{l}\text { Medical schools } \\
\text { with increased } \\
\text { student numbers }\end{array}$ & key & $\begin{array}{l}\text { impact of } \\
\text { expansion on } \\
\text { medical schools }\end{array}$ & exploratory & parallel & atheoretical & $\begin{array}{l}\text { qualitative - } \\
\text { document review, } \\
\text { interviews }\end{array}$ \\
\hline $\begin{array}{l}\text { Patten, D. (2015). "Using ultrasound to } \\
\text { teach anatomy in the undergraduate } \\
\text { medical curriculum: an evaluation of the } \\
\text { experiences of tutors and medical } \\
\text { students." Ultrasound } 23(1): 18-28 .\end{array}$ & unclear & $\begin{array}{l}\text { Use of portable } \\
\text { ultrasound for } \\
\text { teaching anatomy } \\
\text { to medical students } \\
\text { at two medical } \\
\text { schools }\end{array}$ & local & $\begin{array}{l}\text { Experience of staff } \\
\text { and students }\end{array}$ & exploratory & retrospective & atheoretical & $\begin{array}{l}\text { mixed methods - } \\
\text { document review, } \\
\text { interviews, focus } \\
\text { groups, module } \\
\text { evaluations, }\end{array}$ \\
\hline $\begin{array}{l}\text { Pearson, S., et al. (2014). "Supporting } \\
\text { Medical Students to Do International Field } \\
\text { Research: A Case Study." Innovations in } \\
\text { Education and Teaching International } \\
\text { 51(3): 277-291. }\end{array}$ & single & $\begin{array}{l}\text { International field } \\
\text { research of } \\
\text { intercalated } \\
\text { research medical } \\
\text { degree in the UK }\end{array}$ & local & $\begin{array}{l}\text { Health and safety } \\
\text { of medical students } \\
\text { performing } \\
\text { fieldwork }\end{array}$ & exploratory & snapshot & atheoretical & $\begin{array}{l}\text { mixed methods - } \\
\text { questionnaires } \\
\text { survey, document } \\
\text { review }\end{array}$ \\
\hline $\begin{array}{l}\text { Pereira, M. A., et al. (2015). "Medical } \\
\text { student stress: an elective course as a } \\
\text { possibility of help." BMC Res Notes 8: } 430 .\end{array}$ & single & $\begin{array}{l}\text { Personal changes in } \\
\text { medical students } \\
\text { who attended an } \\
\text { elective course on } \\
\text { coping strategies }\end{array}$ & key & $\begin{array}{l}\text { Medical student } \\
\text { stress }\end{array}$ & exploratory & retrospective & atheoretical & $\begin{array}{l}\text { qualitative - } \\
\text { interviews, recording } \\
\text { journal club sessions }\end{array}$ \\
\hline $\begin{array}{l}\text { Perley, C. M. (2006). "Physician use of the } \\
\text { curbside consultation to address } \\
\text { information needs: report on a collective } \\
\text { case study." J Med Libr Assoc 94(2): 137- } \\
144 .\end{array}$ & multiple & $\begin{array}{l}\text { Physician use of } \\
\text { curb-side } \\
\text { consultation - but } \\
\text { unclear what the } \\
\text { 'groups' of } \\
\text { physicians } \\
\text { represented }\end{array}$ & local & $\begin{array}{l}\text { Physician } \\
\text { information- } \\
\text { seeking behaviour }\end{array}$ & exploratory & snapshot & atheoretical & $\begin{array}{l}\text { qualitative - field } \\
\text { notes and interviews }\end{array}$ \\
\hline $\begin{array}{l}\text { Pimmer, C., et al. (2013). "Mobile learning } \\
\text { in resource-constrained environments: a } \\
\text { case study of medical education." Med } \\
\text { Teach 35(5): e1157-1165. }\end{array}$ & $\begin{array}{l}\text { multiple } \\
\text {-unclear } \\
\text { if cases } \\
\text { were } \\
\text { different } \\
\text { sites or } \\
\text { groups of } \\
\text { participa } \\
\text { nts }\end{array}$ & $\begin{array}{l}\text { Adoption of mobile } \\
\text { internet technology } \\
\text { by undergraduate } \\
\text { and postgraduate } \\
\text { students for } \\
\text { medical learning in } \\
\text { Nepal }\end{array}$ & key & $\begin{array}{l}\text { The role of ICT in } \\
\text { medical education } \\
\text { in developing } \\
\text { countries }\end{array}$ & exploratory & snapshot & theoretical & $\begin{array}{l}\text { qualitative - focus } \\
\text { groups of students, } \\
\text { postgraduates, } \\
\text { teachers, faculty }\end{array}$ \\
\hline
\end{tabular}


Improving case study research in medical education: Systematised review

\begin{tabular}{|c|c|c|c|c|c|c|c|c|}
\hline $\begin{array}{l}\text { Preston, R., et al. (2016). "Building blocks } \\
\text { for social accountability: a conceptual } \\
\text { framework to guide medical schools." } \\
\text { BMC Med Educ 16(1): } 227 \text {. }\end{array}$ & multiple & $\begin{array}{l}\text { Medical school - } 4 \\
\text { of the Training for } \\
\text { Health Equity } \\
\text { Network (THEnet) }\end{array}$ & outlier & $\begin{array}{l}\text { Building socially } \\
\text { accountable } \\
\text { medical schools }\end{array}$ & intrinsic & parallel & theoretical & $\begin{array}{l}\text { qualitative - } \\
\text { document review, } \\
\text { field notes, visits }\end{array}$ \\
\hline $\begin{array}{l}\text { Preston, R., et al. (2016). "From personal } \\
\text { to global: Understandings of social } \\
\text { accountability from stakeholders at four } \\
\text { medical schools." Med Teach 38(10): } 987 \text { - } \\
994 \text {. }\end{array}$ & multiple & $\begin{array}{l}\text { Socially } \\
\text { accountable } \\
\text { medical schools (4) }\end{array}$ & outlier & $\begin{array}{l}\text { Conceptions of } \\
\text { social } \\
\text { accountability by } \\
\text { staff, students and } \\
\text { community } \\
\text { members }\end{array}$ & exploratory & retrospective & theoretical & $\begin{array}{l}\text { qualitative, } \\
\text { interviews, } \\
\text { document review, } \\
\text { field notes }\end{array}$ \\
\hline $\begin{array}{l}\text { Pugsley, L. (2008). "Expectation and } \\
\text { experience: dissonances between novice } \\
\text { and expert perceptions in medical } \\
\text { education research." Med Educ 42(9): } \\
\text { 866-871. }\end{array}$ & single & $\begin{array}{l}\text { Perceptions of } \\
\text { novices and experts } \\
\text { at a one-day } \\
\text { research } \\
\text { consortium }\end{array}$ & key & $\begin{array}{l}\text { Variable research } \\
\text { skills in medical } \\
\text { education research }\end{array}$ & exploratory & snapshot & atheoretical & $\begin{array}{l}\text { qualitative - observer } \\
\text { notes, reflective } \\
\text { participant accounts }\end{array}$ \\
\hline $\begin{array}{l}\text { Pugsley, L., et al. (2008). "Making a } \\
\text { difference: researching master's and } \\
\text { doctoral research programmes in medical } \\
\text { education." Med Educ 42(2): 157-163. }\end{array}$ & single & $\begin{array}{l}\text { Masters of Med Ed } \\
\text { and Doctoral } \\
\text { projects } \\
\text { contribution to } \\
\text { scholarship in } \\
\text { medical education }\end{array}$ & local & $\begin{array}{l}\text { Quality of research } \\
\text { methods in higher } \\
\text { degree studies in } \\
\text { medical education }\end{array}$ & exploratory & embedded & atheoretical & $\begin{array}{l}\text { qualitative - website, } \\
\text { Document review, } \\
\text { surveys, interviews, } \\
\text { dissertation review }\end{array}$ \\
\hline $\begin{array}{l}\text { Quinn, E. M., et al. (2014). "Surgical } \\
\text { journal club as a community of practice: a } \\
\text { case study." J Surg Educ 71(4): 606-612. }\end{array}$ & single & $\begin{array}{l}\text { A Surgical journal } \\
\text { club }\end{array}$ & local & $\begin{array}{l}\text { Learning through a } \\
\text { community of } \\
\text { practice }\end{array}$ & exploratory & snapshot & theoretical & $\begin{array}{l}\text { qualitative - } \\
\text { recording of journal } \\
\text { club session, } \\
\text { interviews }\end{array}$ \\
\hline $\begin{array}{l}\text { Quintana, F., et al. (2012). "Assessment of } \\
\text { a Complementary Curricular Strategy for } \\
\text { Training South African Physicians in a } \\
\text { Cuban Medical University." MEDICC } \\
\text { Review 14(3): 19-25. }\end{array}$ & single & $\begin{array}{l}\text { Cuban medical } \\
\text { training of South } \\
\text { African students }\end{array}$ & key & $\begin{array}{l}\text { Factors limiting } \\
\text { success of a } \\
\text { complementary } \\
\text { skills training } \\
\text { program }\end{array}$ & exploratory & retrospective & theoretical & $\begin{array}{l}\text { qualitative, } \\
\text { document review, } \\
\text { interviews, focus } \\
\text { groups, survey }\end{array}$ \\
\hline $\begin{array}{l}\text { Radomski, N. and J. Russell (2010). } \\
\text { "Integrated Case Learning: Teaching } \\
\text { Clinical Reasoning." Advances in Health } \\
\text { Sciences Education 15(2): 251-264. }\end{array}$ & single & $\begin{array}{l}\text { 3rd year } \\
\text { undergraduate } \\
\text { medical students } \\
\text { experience of ICL in } \\
\text { simulation }\end{array}$ & local & $\begin{array}{l}\text { Clinical reasoning in } \\
\text { the Integrated Case } \\
\text { Learning (ICL) } \\
\text { environment }\end{array}$ & exploratory & snapshot & theoretical & $\begin{array}{l}\text { qualitative - focus } \\
\text { group, interviews, } \\
\text { document review, } \\
\text { field observation }\end{array}$ \\
\hline
\end{tabular}


Improving case study research in medical education: Systematised review

\begin{tabular}{|c|c|c|c|c|c|c|c|c|}
\hline $\begin{array}{l}\text { Raman, M., et al. (2008). } \\
\text { "Gastroenterology fellowship training: } \\
\text { approaches to curriculum assessment and } \\
\text { evaluation." Can J Gastroenterol 22(6): } \\
559-564 .\end{array}$ & single & $\begin{array}{l}\text { One } \\
\text { gastroenterology } \\
\text { fellowship program }\end{array}$ & local & $\begin{array}{l}\text { Utilisation of the } \\
\text { Kern model of } \\
\text { curriculum } \\
\text { development for } \\
\text { curriculum } \\
\text { assessment }\end{array}$ & instrumental & snapshot & theoretical & $\begin{array}{l}\text { qualitative - } \\
\text { document review, } \\
\text { interview }\end{array}$ \\
\hline $\begin{array}{l}\text { Rego, P., et al. (2009). "Using a structured } \\
\text { clinical coaching program to improve } \\
\text { clinical skills training and assessment, as } \\
\text { well as teachers' and students' } \\
\text { satisfaction." Med Teach 31(12): e586- } \\
595 .\end{array}$ & single & $\begin{array}{l}\text { a Structured Clinical } \\
\text { Coaching Program } \\
\text { to support student } \\
\text { learning }\end{array}$ & local & $\begin{array}{l}\text { Evaluation of } \\
\text { clinical skills } \\
\text { training and } \\
\text { assessment }\end{array}$ & evaluative & retrospective & atheoretical & $\begin{array}{l}\text { mixed methods - } \\
\text { formative } \\
\text { assessment, costs, } \\
\text { interviews }\end{array}$ \\
\hline $\begin{array}{l}\text { Risor, T. (2016). "Trail Blazing or Jam } \\
\text { Session? Towards a New Concept of } \\
\text { Clinical Decision-making." Anthropol Med: } \\
\text { 1-18. }\end{array}$ & single & $\begin{array}{l}\text { intern clinical } \\
\text { decision making }\end{array}$ & key & $\begin{array}{l}\text { clinical decision } \\
\text { making }\end{array}$ & exploratory & diachronic & theoretical & $\begin{array}{l}\text { qualitative - } \\
\text { ethnographic, } \\
\text { document review, } \\
\text { field notes, interview }\end{array}$ \\
\hline $\begin{array}{l}\text { Rodriguez, C, et al (2014). "Family } \\
\text { physicians' professional identify } \\
\text { formation: a study protocol to explore } \\
\text { impression management processes in } \\
\text { institutional academic contexts."BMC } \\
\text { Med Ed 14:184 }\end{array}$ & multiple & $\begin{array}{l}4 \text { Medical schools, } \\
4 \text { embedded units }\end{array}$ & key & $\begin{array}{l}\text { Professional } \\
\text { identification and } \\
\text { reputation of family } \\
\text { medicine }\end{array}$ & exploratory & parallel & theoretical & $\begin{array}{l}\text { qualitative - } \\
\text { interviews, } \\
\text { document review }\end{array}$ \\
\hline $\begin{array}{l}\text { Rodriguez, C., et al. (2015). "The influence } \\
\text { of academic discourses on medical } \\
\text { students' identification with the discipline } \\
\text { of family medicine." Acad Med 90(5): 660- } \\
670 .\end{array}$ & multiple & $\begin{array}{l}\text { Professional } \\
\text { identification and } \\
\text { reputation of family } \\
\text { medicine at } 4 \\
\text { Medical schools, } 4 \\
\text { embedded units }\end{array}$ & key & $\begin{array}{l}\text { Influence of } \\
\text { features, } \\
\text { knowledge and } \\
\text { skills required, } \\
\text { prestige, student } \\
\text { and educator } \\
\text { attitudes } \\
\end{array}$ & exploratory & parallel & theoretical & $\begin{array}{l}\text { qualitative - } \\
\text { interviews, } \\
\text { document review }\end{array}$ \\
\hline $\begin{array}{l}\text { Rodriguez, C., et al. (2012). "Exploring } \\
\text { professional identification and reputation } \\
\text { of family medicine among medical } \\
\text { students: a Canadian case study." Educ } \\
\text { Prim Care 23(3): 158-168. }\end{array}$ & single & $\begin{array}{l}\text { Professional } \\
\text { identification and } \\
\text { reputation of family } \\
\text { medicine of } \\
\text { medical students }\end{array}$ & local & $\begin{array}{l}\text { medical student } \\
\text { perceptions of } \\
\text { family medicine }\end{array}$ & exploratory & snapshot & theoretical & $\begin{array}{l}\text { qualitative - } \\
\text { interviews, } \\
\text { document review }\end{array}$ \\
\hline $\begin{array}{l}\text { Savage, C. and M. Brommels (2008). } \\
\text { "Innovation in medical education: how } \\
\text { Linkoping created a Blue Ocean for } \\
\text { medical education in Sweden." Med Teach } \\
\text { 30(5): 501-507. }\end{array}$ & single & $\begin{array}{l}\text { Revolutionary } \\
\text { curricular change at } \\
\text { Linkoping Health } \\
\text { University }\end{array}$ & key & $\begin{array}{l}\text { Strategy and } \\
\text { Innovation in } \\
\text { medical education }\end{array}$ & exploratory & retrospective & theoretical & $\begin{array}{l}\text { qualitative - } \\
\text { document review } \\
\text { and participant input }\end{array}$ \\
\hline
\end{tabular}


Improving case study research in medical education: Systematised review

\begin{tabular}{|c|c|c|c|c|c|c|c|c|}
\hline $\begin{array}{l}\text { Seluakumaran, K., et al. (2011). } \\
\text { "Integrating an Open-Source Course } \\
\text { Management System (Moodle) into the } \\
\text { Teaching of a First-Year Medical } \\
\text { Physiology Course: A Case Study." } \\
\text { Advances in Physiology Education 35(4): } \\
\text { 369-377. }\end{array}$ & single & $\begin{array}{l}\text { teaching first year } \\
\text { medical physiology } \\
\text { through an open- } \\
\text { source course } \\
\text { management } \\
\text { system }\end{array}$ & local & $\begin{array}{l}\text { Use of open-source } \\
\text { course } \\
\text { management } \\
\text { systems to support } \\
\text { teaching }\end{array}$ & evaluative & retrospective & atheoretical & $\begin{array}{l}\text { quantitative- Usage } \\
\text { stats, exam results, } \\
\text { questionnaire, }\end{array}$ \\
\hline $\begin{array}{l}\text { Sharif-Chan, B., et al. (2016). "An } \\
\text { Observational Case Study of Near-peer } \\
\text { Teaching in Medical and Pharmacy } \\
\text { Experiential Training." Am J Pharm Educ } \\
80(7): 114 .\end{array}$ & single & $\begin{array}{l}\text { near peer teaching } \\
\text { used by medical } \\
\text { and pharmacy } \\
\text { trainees at one } \\
\text { academic teaching } \\
\text { site }\end{array}$ & local & $\begin{array}{l}\text { Observation and } \\
\text { perceptions of } \\
\text { near-peer teaching } \\
\text { in experiential } \\
\text { training }\end{array}$ & exploratory & embedded & atheoretical & $\begin{array}{l}\text { qualitative - } \\
\text { observations, } \\
\text { interviews }\end{array}$ \\
\hline $\begin{array}{l}\text { Shershneva, M. B., et al. (2008). "Learning } \\
\text { to collaborate: a case study of } \\
\text { performance improvement CME." Journal } \\
\text { of Continuing Education in the Health } \\
\text { Professions 28(3): 140-147. }\end{array}$ & single & $\begin{array}{l}\text { A community- } \\
\text { based primary care } \\
\text { practice and } \\
\text { academic } \\
\text { institution } \\
\text { collaboration to } \\
\text { enhance patient } \\
\text { care for } \\
\text { hypertension }\end{array}$ & local & $\begin{array}{l}\text { Performance } \\
\text { Improvement } \\
\text { Continuing Medical } \\
\text { Education(PI CME) }\end{array}$ & exploratory & snapshot & atheoretical & $\begin{array}{l}\text { qualitative - } \\
\text { participant } \\
\text { observation, } \\
\text { interviews }\end{array}$ \\
\hline $\begin{array}{l}\text { Skipper, M., et al. (2016). "Organisation of } \\
\text { workplace learning: a case study of } \\
\text { paediatric residents' and consultants' } \\
\text { beliefs and practices." Advances in Health } \\
\text { Sciences Education 21(3): 677-694. }\end{array}$ & single & $\begin{array}{l}\text { clinical paediatric } \\
\text { departments - } \\
\text { university/regional, } \\
\text { different health } \\
\text { administration }\end{array}$ & key & $\begin{array}{l}\text { workplace learning } \\
\text { in medical specialist } \\
\text { training }\end{array}$ & exploratory & snapshot & theoretical & $\begin{array}{l}\text { qualitative - } \\
\text { ethnography, focus } \\
\text { groups, interview, } \\
\text { participant } \\
\text { observation }\end{array}$ \\
\hline $\begin{array}{l}\text { Stebbings, S., et al. (2012). "Blended } \\
\text { Learning and Curriculum Renewal across } \\
\text { Three Medical Schools: The Rheumatology } \\
\text { Module at the University of Otago." } \\
\text { Australasian Journal of Educational } \\
\text { Technology 28(7): 1176-1189. }\end{array}$ & single & $\begin{array}{l}\text { Development and } \\
\text { evaluation of an } \\
\text { online module to } \\
\text { teach } \\
\text { rheumatology to } \\
\text { 5th year medicals } \\
\text { students }\end{array}$ & local & $\begin{array}{l}\text { Blended learning } \\
\text { and curriculum } \\
\text { renewal in medical } \\
\text { schools }\end{array}$ & $\begin{array}{l}\text { exploratory, } \\
\text { evaluative }\end{array}$ & diachronic & atheoretical & $\begin{array}{l}\text { Qualitative - } \\
\text { interviews, focus } \\
\text { groups, assessments }\end{array}$ \\
\hline $\begin{array}{l}\text { Struwig, M. C., et al. (2016). "Reasons for } \\
\text { Suboptimal Learning in Medical } \\
\text { Microbiology." Teaching in Higher } \\
\text { Education 21(5): 590-609. }\end{array}$ & single & $\begin{array}{l}\text { student learning } \\
\text { with introduction } \\
\text { of a medical } \\
\text { microbiology board } \\
\text { game }\end{array}$ & key & $\begin{array}{l}\text { medical } \\
\text { microbiology } \\
\text { teaching and } \\
\text { learning }\end{array}$ & exploratory & sequential & theoretical & $\begin{array}{l}\text { mixed methods - } \\
\text { questionnaires, focus } \\
\text { groups }\end{array}$ \\
\hline
\end{tabular}


Improving case study research in medical education: Systematised review

\begin{tabular}{|c|c|c|c|c|c|c|c|c|}
\hline $\begin{array}{l}\text { Taytiwat, P. F., J Briggs, D The Thai- } \\
\text { Australian Health Alliance: A Case Study of } \\
\text { Inter-Organisational Collaboration. }\end{array}$ & single & $\begin{array}{l}\text { The Thai-Australian } \\
\text { Health Alliance }\end{array}$ & local & $\begin{array}{l}\text { Cross-cultural } \\
\text { strategic alliances }\end{array}$ & exploratory & diachronic & theoretical & $\begin{array}{l}\text { qualitative - field } \\
\text { notes, interviews, } \\
\text { questionnaires, } \\
\text { document review }\end{array}$ \\
\hline $\begin{array}{l}\text { Tomolo, A. M., et al. (2009). "A case study } \\
\text { of translating ACGME practice-based } \\
\text { learning and improvement requirements } \\
\text { into reality: systems quality improvement } \\
\text { projects as the key component to a } \\
\text { comprehensive curriculum." Postgrad } \\
\text { Med J 85(1008): 530-537. }\end{array}$ & single & $\begin{array}{l}\text { Development and } \\
\text { evaluation of a PBLI } \\
\text { curriculum for } \\
\text { residency training }\end{array}$ & local & $\begin{array}{l}\text { Practice-Based } \\
\text { Learning and } \\
\text { Improvement } \\
\text { curriculum for } \\
\text { residency training }\end{array}$ & $\begin{array}{l}\text { exploratory, } \\
\text { evaluative }\end{array}$ & diachronic & theoretical & $\begin{array}{l}\text { Mixed - } \\
\text { questionnaire, } \\
\text { interviews, document } \\
\text { review }\end{array}$ \\
\hline $\begin{array}{l}\text { Van Hoof, T. J., et al. (2009). "A case study } \\
\text { of medical grand rounds: are we using } \\
\text { effective methods?" Acad Med 84(8): } \\
\text { 1144-1151. }\end{array}$ & single & $\begin{array}{l}\text { Medical Grand } \\
\text { Rounds at an } \\
\text { academic medical } \\
\text { centre }\end{array}$ & key & $\begin{array}{l}\text { Evidence-based } \\
\text { educational } \\
\text { practice }\end{array}$ & $\begin{array}{l}\text { Instrumental } \\
\text {, exploratory }\end{array}$ & snapshot & theoretical & $\begin{array}{l}\text { Qualitative - } \\
\text { document review, } \\
\text { focus group, } \\
\text { interviews }\end{array}$ \\
\hline $\begin{array}{l}\text { Van Hoof, T. J., et al. (2009). "Improving } \\
\text { medical grand rounds: barriers to } \\
\text { change." Conn Med 73(9): 545-551. }\end{array}$ & single & $\begin{array}{l}\text { Medical Grand } \\
\text { Rounds at an } \\
\text { academic medical } \\
\text { centre }\end{array}$ & key & $\begin{array}{l}\text { perceived barriers } \\
\text { to improving a } \\
\text { Medical Grand } \\
\text { Rounds program }\end{array}$ & $\begin{array}{l}\text { Instrumental } \\
\text {, exploratory }\end{array}$ & snapshot & theoretical & $\begin{array}{l}\text { Qualitative - } \\
\text { document review, } \\
\text { focus group, } \\
\text { interviews }\end{array}$ \\
\hline $\begin{array}{l}\text { Wong, A. K. (2011). "Culture in medical } \\
\text { education: comparing a Thai and a } \\
\text { Canadian residency programme." Med } \\
\text { Educ 45(12): 1209-1219. }\end{array}$ & multiple & $\begin{array}{l}\text { anaesthesia } \\
\text { residency training } \\
\text { programs in } \\
\text { Thailand and } \\
\text { Canada } \\
\end{array}$ & key & $\begin{array}{l}\text { impact of culture } \\
\text { on medical } \\
\text { education }\end{array}$ & $\begin{array}{l}\text { Instrumental } \\
\text {, exploratory }\end{array}$ & embedded & theoretical & $\begin{array}{l}\text { mixed methods - } \\
\text { document review, } \\
\text { observations, survey, } \\
\text { interviews }\end{array}$ \\
\hline $\begin{array}{l}\text { Wong, B. M., et al. (2013). "Sustaining } \\
\text { quality improvement and patient safety } \\
\text { training in graduate medical education: } \\
\text { lessons from social theory." Acad Med } \\
88(8): 1149-1156 .\end{array}$ & single & $\begin{array}{l}\text { Implementation of } \\
\text { QI/PS curricula in } \\
\text { residency clinical } \\
\text { training }\end{array}$ & key & $\begin{array}{l}\text { sustainable quality } \\
\text { improvement and } \\
\text { patient safety } \\
\text { training in medical } \\
\text { education }\end{array}$ & exploratory & retrospective & theoretical & $\begin{array}{l}\text { qualitative - } \\
\text { interviews with } \\
\text { participants from } \\
\text { different academic } \\
\text { institutions in } \\
\text { different countries }\end{array}$ \\
\hline $\begin{array}{l}\text { Wong, YW., et al. (2014). "Teachers' } \\
\text { perceptions of and responses to student } \\
\text { evaluation of teaching: purposes and uses } \\
\text { in clinical education." Assessment \& } \\
\text { Evaluation in Higher Education 39(4): 397- } \\
411 .\end{array}$ & single & $\begin{array}{l}\text { Student evaluation } \\
\text { of clinical teaching } \\
\text { (SET) in an } \\
\text { undergraduate } \\
\text { medicine program }\end{array}$ & local & $\begin{array}{l}\text { Clinical teachers } \\
\text { perceptions of and } \\
\text { responses to SET }\end{array}$ & $\begin{array}{l}\text { instrumental } \\
\text {, exploratory }\end{array}$ & snapshot & theoretical & $\begin{array}{l}\text { Qualitative - survey } \\
\text { and interview } \\
\text { (sequential) }\end{array}$ \\
\hline
\end{tabular}


Improving case study research in medical education: Systematised review

\begin{tabular}{|c|c|c|c|c|c|c|c|c|}
\hline $\begin{array}{l}\text { Worley, P., et al. (2006). "Empirical } \\
\text { evidence for symbiotic medical education: } \\
\text { a comparative analysis of community and } \\
\text { tertiary-based programmes." Med Educ } \\
40(2): 109-116 .\end{array}$ & multiple & $\begin{array}{l}\text { 3rd year medical } \\
\text { student } \\
\text { perceptions of } \\
\text { clinical placements }\end{array}$ & local & $\begin{array}{l}\text { Symbiotic medical } \\
\text { education }\end{array}$ & exploratory & diachronic & atheoretical & $\begin{array}{l}\text { Qualitative - student } \\
\text { interviews ( } 2 \text { groups, } \\
n=22 \text { ) }\end{array}$ \\
\hline $\begin{array}{l}\text { Yates, J. (2011). "Development of a } \\
\text { 'toolkit' to identify medical students at risk } \\
\text { of failure to thrive on the course: an } \\
\text { exploratory retrospective case study." } \\
\text { BMC Med Educ 11: } 95 .\end{array}$ & single & $\begin{array}{l}\text { Student progress } \\
\text { through a medical } \\
\text { school }\end{array}$ & local & $\begin{array}{l}\text { Identifying medical } \\
\text { students at risk of } \\
\text { academic failure }\end{array}$ & exploratory & retrospective & atheoretical & $\begin{array}{l}\text { Mixed - Document } \\
\text { review, Student } \\
\text { demographics, exam } \\
\text { marks, }\end{array}$ \\
\hline
\end{tabular}

